\title{
Trophic niche segregation in the Nilotic ichthyofauna of Lake Albert (Uganda, Africa)
}

\author{
Linda M. Campbell ${ }^{\mathrm{a}, \mathrm{d}}$, Sylvester B. Wandera ${ }^{\mathrm{b}}$, Robert J. Thacker ${ }^{\mathrm{c}, \mathrm{e}}$, D. George Dixon ${ }^{\mathrm{a}}$ \& Robert E. \\ Hecky $^{\mathrm{a}}$ \\ ${ }^{a}$ Department of Biology, University of Waterloo, 200 University Avenue. Waterloo, Ontario, Canada \\ N2L $3 G 1$ \\ ${ }^{\mathrm{b}}$ Fisheries Resources Research Institute, P.O. Box 343, Jinja, Uganda \\ ${ }^{\mathrm{c}}$ Department of Physics and Astronomy, McMaster University, 1280 Main St. W, Hamilton, Ontario, Canada \\ ${ }^{\mathrm{d}}$ Current address: School of Environmental Studies and Department of Biology, Queen's University, Kingston, \\ ON, CanadaK7L3N6 (e-mail: campbelm@biology.queensu.ca) \\ ${ }^{\mathrm{e}}$ Current address: Department of Physics and Astronomy, Queen's University, Kingston, ON, Canada \\ K7L 3 N6
}

Received 29 April $2004 \quad$ Accepted 13 February 2005

Key words: $\delta^{13} \mathrm{C}, \delta^{15} \mathrm{~N}$, food webs, Nile perch, stable isotopes

\section{Synopsis}

Nile perch, Lates niloticus, and Nile tilapia, Oreochromis niloticus, were originally transplanted from Lake Albert in western Uganda to the African Great Lakes, Lake Victoria and Lake Kyoga, where they are partially implicated in reduction of the fish species diversity. Lake Albert is facing multiple environmental changes, including declining fish species diversity, hyper-eutrophication, hypoxia, and reduced fish catches. To examine the role of Nile perch and Nile tilapia in the food web in their native Lake Albert, we estimated their diets using stable nitrogen and carbon isotopes. In Lake Albert, the tilapiine congeners (closely related species), Tilapia zillii, Oreochromis leucostictus, and Sarethorodon galilaeus, and the centropomid Nile perch congener, Lates macrophthalmus, have narrower diet breath in the presence of the native $O$. niloticus and L. niloticus. A computerized parameter search of dietary items for five commercially important fish species (Hydrocynus forskahlii, Bagrus bayad, L. niloticus, Alestes baremose and Brycinus nurse) was completed using a static isotopic mixing model. The outcome of the simulation for most fish species compared favorably to previously published stomach contents data for the Lake Albert fishes dating back to 1928, demonstrating agreement between stable isotope values and analyses of stomach contents. While there were some indications of changes in the diets of $L$. niloticus and A. baremose diets over the past 20 years in parallel with other changes in the lake, for the most part, food web structure in this lake remained stable since 1928. The Lake Albert fish assemblage provides insight into the invasion success of L. niloticus and O. niloticus.

\section{Introduction}

Globally, aquatic species introductions are a growing problem, particularly where native species are unable to maintain integrity in the presence of the invaders. The issue of anthropogenic species introductions has grown to pandemic proportions. The international community has broadly recognized this issue, and in response, has established the International Union for Conservation of Nature and Natural Resources's IUCN Red Lists (http://www.iucnredlist.org) and the IUCN 
Invasive Species Specialist Group (http:// www.issg.org). In sub-Saharan Africa, fish introductions from other African lakes and from abroad have been occurring since the mid-1900s. In fact, Nile perch Lates niloticus was listed by the IUCN as being among the top 100 of the world's worst invasive organisms and has been partially implicated in disruptive impacts on aquatic food webs and species diversity in Lake Victoria and across East Africa (Pitcher 1995).

Nile perch and Nile tilapia, Oreochromis niloticus, were introduced to lakes Victoria and Kyoga in the mid-20th century, primarily from Lake Albert in northeastern Uganda. In conjunction with other environmental shifts, these species have been implicated in the decline of the fish species diversity in lakes Victoria and Kyoga (Ogutu-Ohwayo \& Hecky 1991, Kaufman 1992, Goldschmidt et al. 1993, Twongo 1995) However, Lake Albert remains one of the few multi-species commercial fisheries in Uganda that has retained its original Nilotic ichthyofauna (Wandera 2000), and thus this lake represent both the original state of many lakes and provide a reservoir of fish species no longer found in the disrupted systems. The apparently stable co-existence of two Lates species along with the tigerfish, Hydrocynus forskahlii, and the co-existence of the tilapiine species in Lake Albert (Ogutu-Ohwayo \& Hecky 1991, Twongo 1995) are intriguing in light of the inability of many fish species in lakes Kyoga and Victoria to co-exist with the introduced L. niloticus and $O$. niloticus.

Furthermore, Lake Albert is currently undergoing severe environmental degradation (hypereutrophication, anoxia and decreases in both fish diversity and catch), possibly stemming from human activity in the region (Wandera 2000). Despite the importance of the lake as a Nilotic ichthyofauna reservoir and the recent dramatic environmental changes, Lake Albert remains poorly understood with only a few recent reports addressing the lake's ecology after the recent environmental shifts (Ogutu-Ohwayo 1994, Lehman et al. 1998). This adds a sense of urgency for rapid assessment and monitoring of the current status of the fish food web dynamics.

Stable nitrogen $\left(\delta^{15} N\right)$ and carbon $\left(\delta^{13} C\right)$ isotope analysis is now a standard technique in food web studies, and has been successfully applied to aquatic ecosystem research globally (Peterson \& Fry 1987, Hecky \& Hesslein 1995, Davenport \& Bax 2002). Typically, $\delta^{15} \mathrm{~N}$ values have been used to characterize relative trophic position (producer, grazer, consumer, etc.) while $\delta^{13} \mathrm{C}$ values have been used to determine the sources and flow of carbon in a food web. Variations in $\delta^{15} \mathrm{~N}$ and $\delta^{13} \mathrm{C}$ values have been successfully used to describe feeding niches within a population of same fish species ( $\mathrm{Gu}$ et al. 1997) and within aquatic communities (Keough et al. 1998). This study documents the trophic relationships for Lake Albert on the basis of stable isotope analyses. It provides the most diverse food web yet studied for any African lake, with 27 taxa (206 aquatic consumer samples) collected over 3 years. As such, it provides the first opportunity to examine food web structure in a multi-piscivore African system and compare it with other African Great Lakes food webs.

\section{Methods}

We carried out Fisheries Resources Research Institute (FIRRI) sampling expeditions during the dry season (November 1998, 1999 and June 2000) in north-eastern Lake Albert. The sampling sites included four locations around the village of Butiaba (the major fish landings of Songa and Kiina, the Butiaba wetland lagoon, and a popular offshore fishing site), as well as the fish landing at the village of Wanseko near the Nile River outlet. We collected mixed zooplankton vertically with Nansen-type plankton nets $(75-300 \mu \mathrm{m})$. Cyclopoids, particularly Mesocyclops aequatorialis, are dominant in Lake Albert and constitute the majority of zooplankton species in any mixed sample ( $>85 \%$; Lehman et al. 1998). High risk of bilharzia, a parastic disease transmitted by snails, prevented more through sampling of nearshore environments for invertebrates (Kabatereine et al. 1996). Alternatively, we recovered many fresh undigested specimens of hard-to-find fish and invertebrates intact from fish stomach contents; after thorough rinsing with distilled water and removal of the gut contents, these specimens were included in the stable isotope analyses.

We purchased fish directly from fishermen or collected from FIRRI-deployed gill nets. There are 
several predatory species, including two native Nile perch congeners, L. niloticus and Lates macrophthalmus, as well as the tigerfish, Hydrocynus forskahlii. In addition to O. niloticus, there are three other tilapiine species, Oreochromis leucostictus, Sarethorodon galilaeus, and Tilapia zillii. We dissected the fish, with $10-\mathrm{cm}^{3}$ muscle tissue sampled from the lateral white muscle of the larger fish ( $\geq 10 \mathrm{~cm}$ total length). We filleted small fish $(<10 \mathrm{~cm}$ total length) and skinned them to sample all axial muscle. During dissection, the presence of the predominant items in the stomach contents was noted (as well as any empty stomachs). Samples were kept on ice in coolers until they could be transferred to freezers upon return to FIRRI in Jinja.

Protocols for stable isotope analyses have been described in Campbell et al. (2003a, b). Briefly, small sub-samples of freeze-dried fish muscle tissue and whole invertebrates were ground into fine powder. The $\delta^{15} \mathrm{~N}$ and $\delta^{13} \mathrm{C}$ analyses were completed concurrently using a Micromass VGIsochrom Continuous Flow Isotope Ratio Mass Spectrometer (CF-IRMS) at the Environmental Isotope Laboratory, University of Waterloo. The ratios of stable nitrogen isotopes were measured against nitrogen gas in ambient air, as a reference, while stable carbon isotope ratios are expressed relative to PeeDee belemnite standard. The delta notation $(\delta)$ is used to indicate the parts per thousand $(\%)$ difference in the isotopic ratio of the sample from the reference standard. Analytical standards were inserted in every run, and included International Atomic Energy Agency standards (CH6, N1, and N2), in-house walleye and cellulose standards and replicates of an archived Lake Victoria Nile perch sample. Standard deviations (SD) for the standards were $\pm 0.3 \%$ for $\delta^{15} \mathrm{~N}$ and $\pm 0.2 \%$ for $\delta^{13} \mathrm{C}$, and SD's for replicate samples were $\pm 0.16 \%$ for $\delta^{15} \mathrm{~N}$ and $\pm 0.24 \%$ for $\delta^{13} \mathrm{C}$.

Statistical analyses were performed using SYSTAT 10.0 for Windows (SPSS Inc. 1998). Inter-annual and inter-site differences for commonly collected fish species ( $\geq 6$ at each site/date) were tested, and found to be insignificant (ANOVA with Tukey's test, $p>0.05$ ). No significant differences were found for various parameters $\left(\delta^{15} \mathrm{~N}, \delta^{13} \mathrm{C}\right.$, weight, TL) between the sexes for L. macrophthalmus. There were insufficient number of females $(n=3)$ to assess inter-sex differences for L. niloticus but visual examination of the data revealed that the females were within the ranges seen for males. Therefore for this study, fish species from different years, sites and gender were pooled.

We have compared our stable isotope results with a literature review of previous ecological studies spanning over 70 years, which include: (1) historical records from 1923 to 1962 (Worthington 1929, Holden 1963); (2) a 1982-1983 study for similar Nilotic ichthyofaunal assemblage in the Sudd Marsh just north of Lake Albert (Hickley \& Bailey 1987); and (3) a L. niloticus study (Ogutu-Ohwayo 1994). Because previous studies on Lake Albert included detailed assessment of the taxonomic composition of fish stomach contents, usually in some form of presence/absence data, we needed to approximate the $\%$ dietary contributions based on our stable isotope data for dietary items. Due to scarce knowledge of the bioenergetics of the fish species in question, it was not possible to use a detailed bioenergetic model (Harvey et al. 2002). Instead, we took a "convergence" approach by combining a simple static linear mixing model (with a mass balance component) and a parameter search to estimate the potential contribution of different dietary items to the somatic growth of five commercially important fish species: the piscivores, H. forskahlii, L. niloticus $(20-60 \mathrm{~cm}$ and $60-100 \mathrm{~cm}$ ) and Bagrus bayad, the insectivore/ piscivore $A$. baremose, and the pelagic B. nurse. Our approach is equivalent to that of Phillips and Gregg (2003) in that we examine the distribution of feasible solutions.

Data for the two size classes of L. niloticus were based on previous work (Ogutu-Ohwayo 1994). Mean values for all sampled invertebrates from fish stomachs (Caridina nilotica, Odonata, Plecoptera) and field samples (zooplankton) were included separately to ensure a broad range of $\delta^{15} \mathrm{~N}$ and $\delta^{13} \mathrm{C}$ values in the dietary simulation. Zooplankton was retained for all fish including the predators, because it was assumed that any predator consuming zooplanktivorous fish would also assimilate their stomach contents. The mean isotopic values of three small fish species (sampled from the wild), Thoracochromis spp., B. nurse, and Sarethorodon galilaeus, known to be important in the diets of the predators were included individually. S. galilaeus was selected as 
the representative tilapiine species because its size range best paralleled the known size ranges of prey tilapiines for Nile perch (3-15 cm; Ogutu-Ohwayo 1994) and its $\delta^{13} \mathrm{C}$ values fell within the $\delta^{13} \mathrm{C}$ ranges of other prey fish. For the smaller fish, only invertebrates were included. The mixing model (Equations 1 and 2) conservatively assumed a fractionation rate of $3.6 \%$ for $\delta^{15} \mathrm{~N}$ and $1.0 \%$ for $\delta^{13} \mathrm{C}$. These values were based on previous work in Lake Victoria (Campbell et al. 2003a, b), which estimated mean fractionation rates of 3.5 to $3.7 \%$ and 0.8 to $1.1 \%$ per trophic transfer respectively for L. niloticus, O. niloticus, and Rastrineobola argentea. Fractionation rates tend to remain similar within species, and are within the range of most estimated fractionation rates for other fish species elsewhere (Pinnegar \& Polunin 1999).

The parameter search explores a discretized solution space of the simultaneous equations in the model and facilitates a calculation of the statistical variation (as $\mathrm{SD}$ ) produced by the parameters in the model. The model and the associated parameter-search were written in FORTRAN (For a copy of the program, contact the first author). The equations for the model are:

$$
\begin{aligned}
& \text { Estimated predator } \delta^{15} \mathrm{~N} \\
& =\left(\left(\delta^{15} \mathrm{~N}_{i}^{\text {prey }} * \% \text { diet }_{i}\right)\right. \\
& \left.\quad+\left(\delta^{15} \mathrm{~N}_{j}^{\text {prey }} * \% \operatorname{diet}_{j}\right) \ldots\right)+3.6 \%
\end{aligned}
$$

$$
\begin{aligned}
& \text { Estimated predator } \delta^{13} \mathrm{C} \\
& \quad=\left(\left(\delta^{13} \mathrm{C}_{i}^{\text {prey }} * \% \operatorname{diet}_{i}\right)\right. \\
& \left.\quad+\left(\delta^{13} \mathrm{C}_{j}^{\text {prey }} * \% \operatorname{diet}_{j}\right) \ldots\right)+1.0 \%
\end{aligned}
$$

To reduce the size of the searched parameter space, different proportions of potential prey for each species were adjusted by $1 \%$ (including the possibility of a $0 \%$ contribution), with the final sum always equaling $100 \%$. This was continued until the estimated isotopic values of the species matched both the actual mean $\delta^{15} \mathrm{~N}$ and $\delta^{13} \mathrm{C}$ values $\left( \pm 0.2^{\%} \%\right)$. Because both $\delta^{15} \mathrm{~N}$ and $\delta^{13} \mathrm{C}$ values had to be simultaneously matched, this placed a constraint on the number of possible dietary combinations. The maximum number of repetitions was set at 80 million, with all simulated dietary proportions that matched the mean isotopic values saved, although in practice the $1 \%$ granulation employed prevented this from being reached. Technically, we have conducted a "parameter search", but in this paper we will refer to this as a "simulation".

The simulated dietary patterns are the result of a computed "list" of all possible combinations of known prey that could result in matching pairwise values that, after trophic fractionation addition, were the same as the actual mean $\delta^{15} \mathrm{~N}$ and $\delta^{13} \mathrm{C}$ values for the fish species in question. The value of this simulation is that it takes advantage of the fact fish assimilate the isotopic values of their diet over time, incorporating variety in their diet. Conversely, stomach contents represent a 'snapshot' of the diet at the time of sampling. In addition, stomach content analyses require timeconsuming identification of species and to measurement of volume/mass of each species found in stomachs (assuming relatively little digestion). However, stable isotope analyses are rapid and inexpensive. While we are aware that this simulation cannot substitute for detailed taxonomic stomach content analyses (which requires a high number of sampled fish frequently sampled around the year), it provides an indirect means for both interpreting the information provided by stable isotope analyses for Lake Albert and comparing results to published stomach content studies from other times and sites.

As the published fish diet studies had only frequency of occurrence of each prey item for each fish species, we assumed that any dietary item with a high frequency of occurrence would be an important item for the fish, and ranked these in terms of importance. Ideally, a proper assessment of the simulation outcome would compare this to published \% mass stomach content data. This parameter search provides a tool to interpret our data, especially in light of the scarce information that is available on modern fish ecology in this lake.

\section{Results and discussion}

\section{Food web structure}

Plotting $\delta^{15} \mathrm{~N}$ values against $\delta^{13} \mathrm{C}$ values provides a visual characterization of food web structure and can be used to assess predator-prey and size cohort relationships (Figure 1). The overall shape of the 


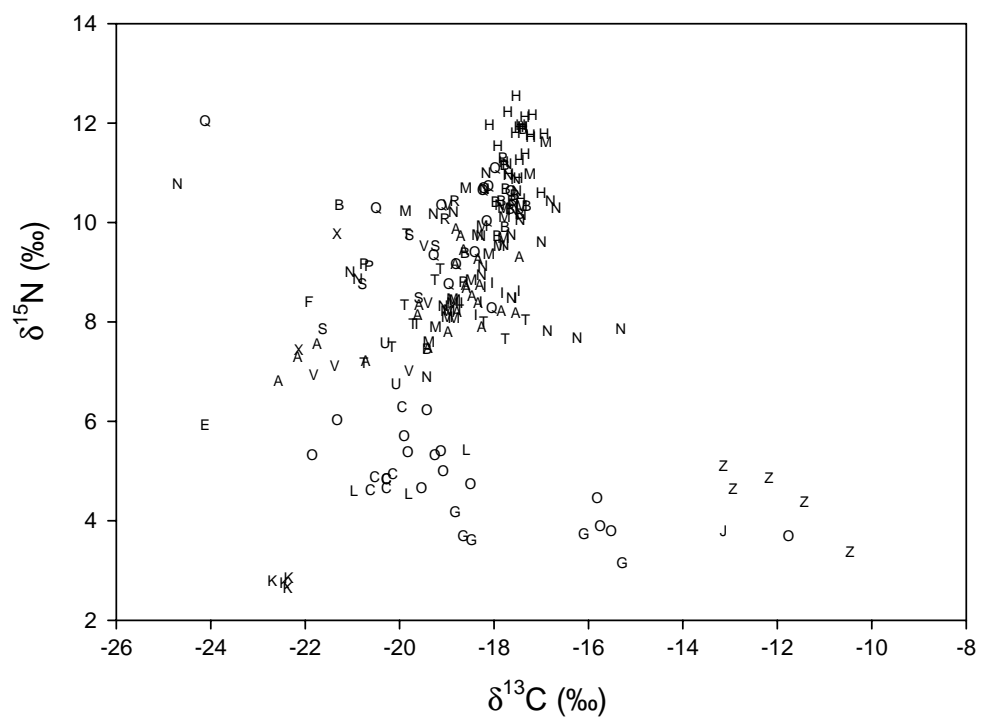

Figure 1. Stable isotope diagram for Lake Albert. The $\delta^{13} \mathrm{C}$ values on the $x$-axis represent potential carbon sources whereas $\delta^{15} \mathrm{~N}$ on the $y$-axis generally can be interpreted as trophic level. Refer to Table 1 for the code key.

Lake Albert food web is triangular, with $H$. forskahlii at the apex and the tilapiines forming the broader base. There is a wide range of $\delta^{15} \mathrm{~N}$ values $(2.7-12.5 \%)$ from the invertebrates to piscivores (i.e. H. forskahlii), while $\delta^{13} \mathrm{C}$ values at the base of the food web range from -24.7 to $-10.5 \%$. The overlap of $\delta^{15} \mathrm{~N}$ values among species throughout the food web indicates a large degree of omnivory and feeding at more than one trophic level. Many fish species in Lake Albert have $\delta^{13} \mathrm{C}$ values that fall between $-22 \%$ and $-16 \%$, indicating that common pool of organic carbon with relatively depleted carbon isotopic signatures may be most important to the majority of fish species (assuming that $\delta^{13} \mathrm{C}$ increases by $0.8-1 \%$ for each trophic transfer). Relatively enriched $\delta^{13} \mathrm{C}$ values were only found for all $T$. zillii, one $O$. niloticus and an anisopteran nymph ( -10 to $-13 \%$ ), suggesting that those individuals consume a more enriched source of carbon.

\section{Nile perch-interspecies and inter-lake comparison}

The two Lates species in Lake Albert are genetically different (Hauser et al. 1998) and morphologically differentiated by their peduncle-to-caudal fin ratios, head proportions and the proportionally larger eye size in L. niloticus. The two Nile perch species are also thought to be ecologically segregated, with the smaller L. macrophthalmus occupying deeper offshore pelagic habitats while L. niloticus, which grows to larger sizes, occupying many habitats across the lake (Worthington 1929). Anecdotal information also suggests that L. macrophthalmus and L. niloticus may breed at different times of the year (Worthington 1929). L. macrophthalmus may grow at slower rates than L. niloticus (Holden 1963), and mature at a smaller size $(25 \mathrm{~cm} \mathrm{TL})$ than L. niloticus $(\leq 45 \mathrm{~cm} ; \mathrm{S}$. B. Wandera, personal data). Both species are visual predators, but we observed different stomach contents composition for each species with C. nilotica and small haplochromine species common in L. macrophthalmus stomachs. We found insects, C. niloti$c a$, detritus and assorted fish remains in L. niloticus (Table 1).

There were no significant differences between these two Lates species within the same size range $(20-60 \mathrm{~cm})$ for either $\delta^{15} \mathrm{~N}(t=-0.002$; df $=38$; $p=0.999) \quad$ or $\delta^{13} \mathrm{C} \quad(t=-0.653 ; \quad \mathrm{df}=42.3$; $p=0.518)$ values. These similar isotopic values contrast with apparent ecological differences between the two species, and in this $20-60 \mathrm{~cm}$ size range, they may compete for similar prey. The range and $\mathrm{SD}$ of $\delta^{13} \mathrm{C}$ values for L. macrophthalmus, 
Table 1. Fish and invertebrates collected in this study with the assigned codes used in the figures. The number of samples $(n)$ for each taxa are listed along with the mean values $\left( \pm\right.$ SD) for total length (TL), and weight $(\mathrm{WT})$, as well as stable nitrogen $\left(\delta^{15} \mathrm{~N}\right)$ and carbon $\left(\delta^{13} \mathrm{C}\right)$ isotope values. The older species names for some species are included in brackets.

\begin{tabular}{|c|c|c|c|c|c|c|c|c|}
\hline Taxa (abbreviation) & Family & Code & $n$ & Stomach contents & $\mathrm{TL}(\mathrm{cm})$ & WT (g) & $\delta^{15} \mathrm{~N}(\%)$ & $\delta^{13} \mathrm{C}(\%)$ \\
\hline \multicolumn{9}{|l|}{ Piscivores } \\
\hline Hydrocynus forskahlii & Alestiidae & $\mathrm{H}$ & 22 & Fish (N, assorted) & $45.5 \pm 8.5$ & $1321 \pm 1664$ & $11.6 \pm 0.5$ & $-17.5 \pm 0.3$ \\
\hline Lates macrophthalmus & Centropomidae & M & 19 & Fish $(\mathrm{M}, \mathrm{R}), \mathrm{C}$ & $32.7 \pm 9.4$ & $453 \pm 450$ & $9.3 \pm 1.1$ & $-18.4 \pm 0.7$ \\
\hline Lates niloticus & Centropomidae & $\mathrm{N}$ & 30 & Fish $(\mathrm{A}, \mathrm{T}), \mathrm{C}, \mathrm{J}$ & $43.7 \pm 31.1$ & $3180 \pm 7554$ & $9.7 \pm 1.1$ & $-18.2 \pm 1.7$ \\
\hline Bagrus bayad & Bagridae & $\mathrm{B}$ & 16 & Fish (R) & $52.0 \pm 9.8$ & $1291 \pm 1245$ & $10.0 \pm 1.2$ & $-18.2 \pm 1.1$ \\
\hline Clarias gariepinus & Clariidae & $\mathrm{V}$ & 2 & - & $59.0-78.0$ & $1600-4000$ & $9.5-10.4$ & -19.5 to -19.0 \\
\hline Polypterus senegalus & Polypteridae & $\mathrm{P}$ & 4 & - & $31.4 \pm 3.2$ & $186 \pm 49$ & $9.6 \pm 1.1$ & $-19.5 \pm 1.5$ \\
\hline \multicolumn{9}{|c|}{ Zooplanktivores/insectivores } \\
\hline Brycinus (Alestes)nurse & Alestiidae & Q & 14 & - & $9.5 \pm 1.8$ & $10 \pm 7$ & $10.1 \pm 1.0$ & $-19.0 \pm 1$ \\
\hline Neobola bredoi & Cyprinidae & $\mathrm{R}$ & 2 & - & $<5.0$ & - & $10.1-10.4$ & -19.0 to -18.8 \\
\hline \multicolumn{9}{|l|}{ Insectivores/molluscivores } \\
\hline Schilbe intermedius & Schilbeidae & I & 8 & - & $21.5 \pm 1.0$ & $74 \pm 9$ & $8.5 \pm 0.2$ & $-18.1 \pm 0.4$ \\
\hline Alestes baremose & Alestiidae & A & 23 & $\mathrm{~K}$ & $37.0 \pm 14.5$ & $570 \pm 334$ & $8.4 \pm 0.8$ & $-19.1 \pm 1.4$ \\
\hline $\begin{array}{l}\text { Thoracochromis } \\
\text { (Haplochromis) spp. }\end{array}$ & Cichlidae & $\mathrm{T}$ & 11 & Molluscs & $8.6 \pm 4.3$ & $53 \pm 41^{\mathrm{a}}$ & $8.1 \pm 0.6$ & $-19.1 \pm 1.1$ \\
\hline Barbus bynni & Cyprinidae & $\mathrm{U}$ & 2 & - & $45.1 \pm 14.1$ & $450-2050$ & $6.8-7.6$ & -20.3 to -20.1 \\
\hline Mormyrus caschive & Mormyridae & $\mathrm{V}$ & 4 & Chironomid, algae & $84.9 \pm 31.5$ & $4680 \pm 3111$ & $7.4 \pm 0.7$ & $-20.6 \pm 1.2$ \\
\hline Synodontis schall & Mochokidae & $\mathrm{S}$ & 5 & - & $18.4 \pm 1.2$ & $60 \pm 16$ & $8.9 \pm 0.8$ & $-20.2 \pm 1.0$ \\
\hline Synodontis frontosus & Mochokidae & $\mathrm{F}$ & 1 & Plants & 26 & 150 & 8.4 & -21.9 \\
\hline $\begin{array}{l}\text { Marcusenius } \\
\text { (Gnathonemus) } \\
\text { cyprinoids }\end{array}$ & Mormyridae & $\mathrm{E}$ & 1 & - & 24.3 & 90 & 5.9 & -24.1 \\
\hline \multicolumn{9}{|l|}{ Detritivores } \\
\hline Oreochromis leucostictus & SF. Tilapiine ${ }^{b}$ & $\mathrm{~L}$ & 3 & - & $20.7 \pm 6.3$ & $168 \pm 113$ & $4.7 \pm 0.5$ & $-19.8 \pm 1.2$ \\
\hline Oreochromis niloticus & SF. Tilapiine & $\mathrm{O}$ & 14 & Algae, detritus & $28.1 \pm 5.1$ & $456 \pm 337$ & $5.0 \pm 0.8$ & $-18.3 \pm 2.7$ \\
\hline Sarethorodon galilaeus & SF. Tilapiine & G & 5 & Detritus & $13.6 \pm 3.2$ & $60 \pm 48$ & $3.7 \pm 0.4$ & $-17.5 \pm 1.7$ \\
\hline Tilapia zillii & SF. Tilapiine & Z & 5 & Detritus & $14.0 \pm 1.9$ & $39 \pm 19$ & $4.5 \pm 0.7$ & $-12.0 \pm 1.1$ \\
\hline \multicolumn{9}{|l|}{ Invertebrates } \\
\hline Caridina-nilotica & Atyidae & $\mathrm{C}$ & 7 & & - & - & $5.0 \pm 0.6$ & $-20.3 \pm 0.2$ \\
\hline Anisopteran-nymphs & - & $\mathrm{J}$ & 1 & & - & - & 3.8 & -13.1 \\
\hline Plecoptera nymphs & - & $\mathrm{K}$ & 4 & & - & - & $2.8 \pm 0.1$ & $-22.5 \pm 0.2$ \\
\hline Zooplankton & (mixed) & $\mathrm{X}$ & 2 & & - & - & $8.6 \pm 1.7$ & $-21.7 \pm 0.6$ \\
\hline
\end{tabular}

${ }^{\mathrm{a} O n l y} 4$ Thoracochromis individuals were weighed; ${ }^{\mathrm{b}}$ The subfamily Tilapiine is in the family Cichlidae.

however, are narrower $(-19.9$ to $-16.9 \%$, $\mathrm{SD}=0.7)$ than for L. niloticus $(-24.7$ to $-15.3 \%$, $\mathrm{SD}=1.7$; Figure 2). Small L. niloticus $(<30 \mathrm{~cm})$ are more opportunistic and likely exploit a greater range of habitats, especially at smaller sizes as indicated by the larger scatter in $\delta^{15} \mathrm{~N}$ and $\delta^{13} \mathrm{C}$ values as seen in Figure 2. (The wide range of $\delta^{13} \mathrm{C}$ values for the other opportunist, $O$. niloticus is analogous.) This illustrates the potential of $L$. niloticus to consume a variety of prey depending on their availabilities. In Lake Albert, competition is likely reduced when $L$. niloticus grows beyond the maximum size of L. macrophthalmus $(\approx 70 \mathrm{~cm})$. This is underscored by the significant differences in the regressions of stable isotopes against TL: L. niloticus does not show any increase in $\delta^{13} \mathrm{C}$ with $\mathrm{TL}$, and a low rate of change in $\delta^{15} \mathrm{~N}$ with TL (and a reduced $r_{\text {adj }}^{2}$ value), whereas $L$. macrophthalmus reveals a relatively rapid change in $\delta^{13}$ and $\delta^{15} \mathrm{~N}$ with TL (Figure 2; Table 2), likely as it becomes more dependent on pelagic prey. L. macrophthalmus may avoid competition by moving offshore and shifting to a more specialized diet, as the higher correlation of $\delta^{13}$ and $\delta^{15} \mathrm{~N}$ with TL for 

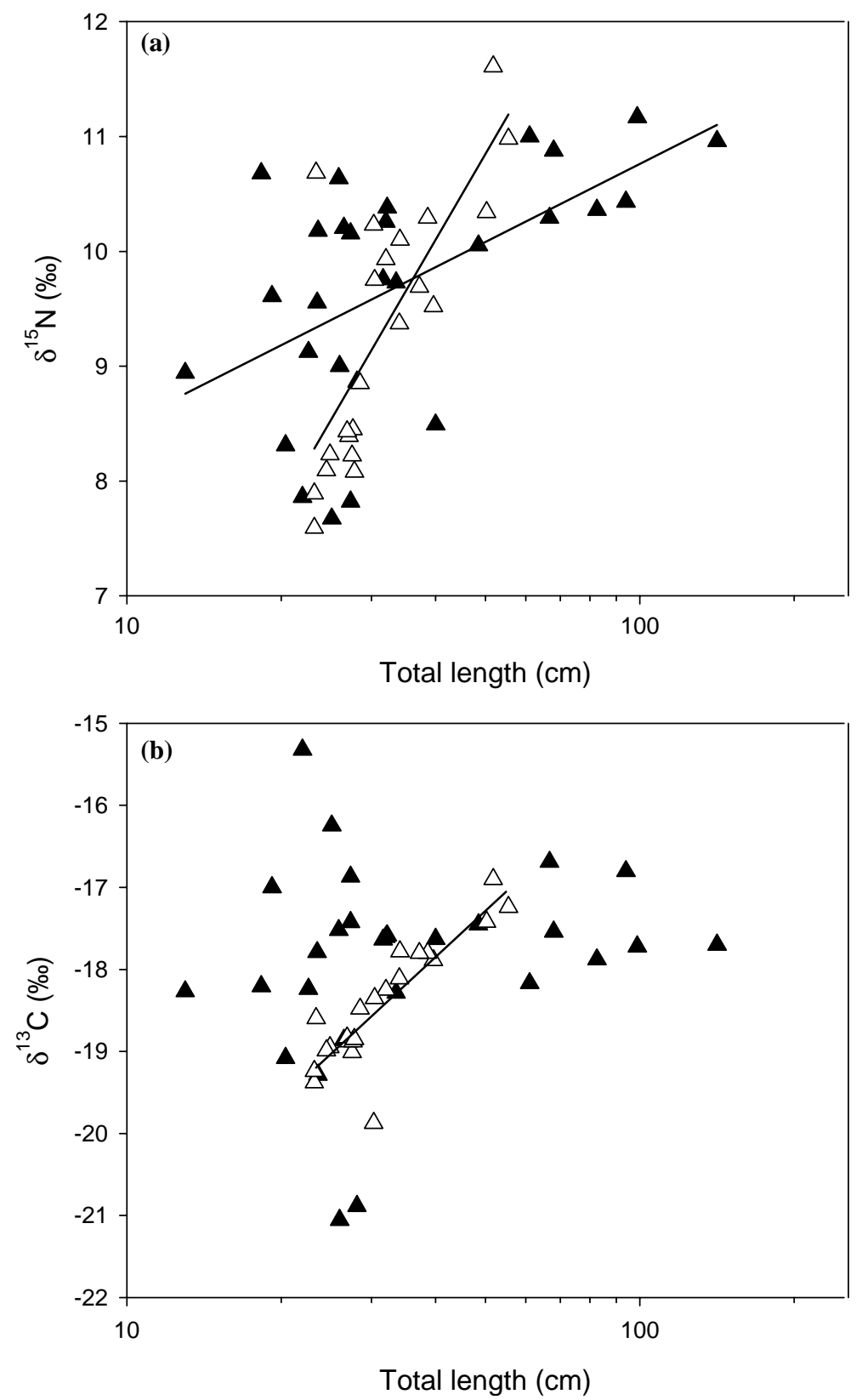

Figure 2. The relationships between $\delta^{15} \mathrm{~N}$ (a) or $\delta^{13} \mathrm{C}$ (b) vs. total length (TL) for Lates macrophthalmus (open triangle) and L. niloticus (closed triangle).

L. macropthalmus suggests reliance upon a narrower range of food items.

Larger L. niloticus have greater fractions of fish in their diets than smaller conspecifics (OgutuOhwayo 1994). This is evident in the trend of increasing $\delta^{15} \mathrm{~N}$ with size for both L. niloticus and L. macrophthalmus (Figure 2). In 1928, the stomachs of the 28 to $63-\mathrm{cm}$ size class L. niloticus contained haplochromines, insects and C. nilotica, while larger $L$. niloticus only had fish remains (bones) in their stomachs (Worthington 1929). However, L. niloticus collected between 1989 and 1992 had a higher frequency of occurrence of fish, especially B. nurse, for both size classes (Table 4). 
Table 2. Regressions of $\delta^{15} \mathrm{~N}$ and $\delta^{13} \mathrm{C}$ values for L. niloticus (Ln), L. macrophthalmus (Lm) and A. baremose (Ab) from Lake Albert (LA) against total length (TL). Published regressions for $L n$ from Napoleon (NG) and Winam Gulfs (WG) in Lake Victoria (Campbell et al. 2003) are included for comparison. For each regression, the sample size $(n)$, the intercept, slope and adjusted $r^{2}$ are listed. The $\delta^{13} \mathrm{C}$ regression for $\mathrm{Ln}$ from LA was excluded from the ANCOVA comparisons due to lack of significance.

\begin{tabular}{|c|c|c|c|c|c|c|c|}
\hline Site & Object & Regression & $n$ & Intercept & Slope & $R_{\mathrm{adj}}^{2}$ & $p$-value \\
\hline \multirow[t]{2}{*}{ LA } & \multirow[t]{2}{*}{$L n$} & $\delta^{15} \mathrm{~N}$ vs TL & \multirow[t]{2}{*}{29} & 8.94 & 0.019 & 0.30 & 0.002 \\
\hline & & $\delta^{13} \mathrm{C}$ vs TL & & -17.92 & -0.005 & 0.00 & 0.377 \\
\hline \multirow[t]{2}{*}{ LA } & \multirow[t]{2}{*}{$\mathrm{Lm}$} & $\delta^{15} \mathrm{~N}$ vs TL & \multirow[t]{2}{*}{21} & 6.45 & 0.088 & 0.53 & $<0.001$ \\
\hline & & $\delta^{13} \mathrm{C}$ vs TL & & -20.64 & 0.068 & 0.72 & $<0.001$ \\
\hline \multirow[t]{2}{*}{$\mathrm{NG}$} & \multirow[t]{2}{*}{$L n$} & $\delta^{15} \mathrm{~N}$ vs TL & \multirow[t]{2}{*}{12} & 5.92 & 0.058 & 0.71 & $<0.001$ \\
\hline & & $\delta^{13} \mathrm{C}$ vs TL & & -19.73 & 0.022 & 0.40 & $<0.001$ \\
\hline \multirow[t]{2}{*}{ WG } & \multirow[t]{2}{*}{$L n$} & $\delta^{15} \mathrm{~N}$ vs TL & \multirow[t]{2}{*}{16} & 9.11 & 0.053 & 0.72 & $<0.001$ \\
\hline & & $\delta^{13} \mathrm{C}$ vs TL & & -23.70 & 0.029 & 0.30 & $<0.001$ \\
\hline \multirow[t]{2}{*}{ LA } & \multirow[t]{2}{*}{$A b$} & $\delta^{15} \mathrm{~N}$ vs TL & \multirow[t]{2}{*}{15} & 2.75 & 0.135 & 0.794 & 0.004 \\
\hline & & $\delta^{13} \mathrm{C}$ vs TL & & -27.71 & 0.195 & 0.63 & $<0.001$ \\
\hline
\end{tabular}

Such a high intake of $B$. nurse during the early 1990's may not be the current situation for L. niloticus, and the modern lower isotopic values for L. niloticus in this study may be due to a reduced intake of $B$. nurse or an increase in consumption of invertebrates and/or cannibalization of its own young. This suggests that a dietary shift might have started in the period between 19881992 and 2000, concurrent with the dramatic shifts in the lake environment associated with overfishing and reduced visibility due to eutrophication (Wandera 2000). Such dietary shifts have already been observed for L. niloticus populations in Lake Victoria that are increasingly reliant on $C$. nilotica and its own young (Campbell et al. 2003a, b). Therefore the indication of dietary shift in Lake Albert may be an early warning of unsustainable pressure, either environmental or fishing, on the Lates populations in this lake.

Some of the Nile perch stock originally introduced to Lake Victoria was drawn from Lake Albert, and present-day Victoria L. niloticus are genetically similar to conspecifics in Lake Albert (Hauser 1998). The Lake Victoria food web is short with only two trophic transfers between invertebrates and Nile perch (Campbell et al. $2003 \mathrm{a}, \mathrm{b})$. Also, the food web in Lake Victoria is considered transitory with rapid changes in prey composition having occurred over the past 30 years (Ogutu-Ohwayo \& Hecky 1991). Using Lake Victoria data (Campbell et al. 2003a, b), processed at the same laboratory using the same techniques, it is possible to compare the rate of change in Nile perch stable isotope values with size in the native and the introduced stocks. Comparing the Albert and Victoria Lates spp., the rates of change for L. macrophthalmus are significantly higher for both $\delta^{13} \mathrm{C}$ (ANCOVA, $p=0.232$ ) and $\delta^{15} \mathrm{~N}(p=0.046)$ with TL than for L. niloticus from both Lakes Victoria and Albert, with Albert L. niloticus having slower rates of change in $\delta^{15} \mathrm{~N}$ with TL (ANCOVA, $p=0.002$ ) than for Victoria Lates (Table 2). Intercepts for all regression slopes are significantly different, indicating that the baseline carbon and nitrogen entering the food web have significantly different isotopic composition for the two Nile perch species from Lake Albert and the two gulfs in Lake Victoria. Within Lake Victoria, ANCOVA analyses of rates of change in $\delta^{15} \mathrm{~N}$ and $\delta^{13} \mathrm{C}$ versus TL for L. niloticus from Napoleon Gulf (Uganda) and Winam Gulf (Kenya) were not significantly different (Campbell et al. 2003a, b). The similar rates of change in the two Victoria gulfs have been attributed to the reduced visibility due to eutrophication, and limitation on the size of dietary prey set by Nile perch's gape size which is approximately 0.114 *TL (Witte \& van Densen 1995). Even though many haplochromine species remain in Lake Victoria, currently, Nile perch does not appear to feed upon those haplochromines (Campbell et al. 2003a, b). In Lake Victoria, L. niloticus shifts to higher trophic level prey with more enriched $\delta^{15} \mathrm{~N}$ more rapidly than the same species in Lake Albert. This rapid shift with size may be a consequence of the smaller diversity of larger prey or greater abundance of prey fish available in Victoria. 


\section{Tilapiine feeding patterns}

The tilapiine species had a relatively narrow range of $\delta^{15} \mathrm{~N}$ values $(3.7-5.0 \%$; Table 1$)$ but their $\delta^{13} \mathrm{C}$ values $(-12$ to $-19.8 \%$ o extend over nearly the entire food web range (Figure 1; Table 1). The size (and growth rates) of different tilapiine species may influence ecological and dietary segregation. For example, the smallest tilapiine species in this group, S. galilaeus, had significantly lower $\delta^{15} \mathrm{~N}$ values (Studentized Tukey's test $=0.105$ to 0.069 , $p<0.05)$ compared to $O$. niloticus and $O$. leucostictus, and those three tilapiine species together exhibited a significant positive correlation between $\delta^{15} \mathrm{~N}$ and TL (Figure 3). However, there are no significant relationships between $\delta^{15} \mathrm{~N}$ or $\delta^{13} \mathrm{C}$ and TL within each of these tilapiine species $(p=0.14$ to 0.35 ).

S. galilaeus, O. leucostictus, and T. zillii differed isotopically (Figure 1). The Butiaba lagoon where we sampled the tilapiines is a heterogenous habitat with high macrophyte density and is open to main lake, which may account for the wide range of $\delta^{13} \mathrm{C}$ values in the tilapiine species. Variation in habitats may reduce direct competition between these species in the Butiaba lagoon, as $S$. galilaeus tend to be more closely associated with submerged vegetation (Hickley \& Bailey 1987). O. leucostictus is more tolerant of fluctuating oxygen and temperature conditions than the other tilapiine species, and therefore probably occupy habitats unavailabile to other tilapiines (Trewavas 1983). $T$. zillii, with its significantly enriched $\delta^{13} \mathrm{C}$ values, forms a distinct group (Studentized Tukey test $=0.051$ to $0.002, p<0.05$ for each pairwise comparison). T. zillii differs from the other tilapiines by having coarse teeth and a diet of coarse detritus and plant material (Trewavas 1983). Common C-4 macrophytes such as Vossia cuspidator, Cyperus papyrus and Vallisneria aethiope have $\delta^{13} \mathrm{C}$ values of about -14 to $-10 \%$ o (Hecky \& Hesslein 1995, Hart et al. 2003). Consequently, the enriched $\delta^{13} \mathrm{C}$ values for $T$. zillii from Lake Albert $(-12.0 \%$ can be attributed to a diet dependent on C-4 macrophyte detritus and benthic algae, also seen for the Sudd T. zillii (Table 4).

Oreochromis niloticus is a wide-ranging species with the ability to feed on detritus as well as invertebrates (Balirwa 1992, Batjakas et al. 1997). $O$. niloticus has widely-established populations in other lake systems where it is not native (OgutuOhwayo \& Hecky 1991). In both the Sudd and Lake Albert, where this species is native,

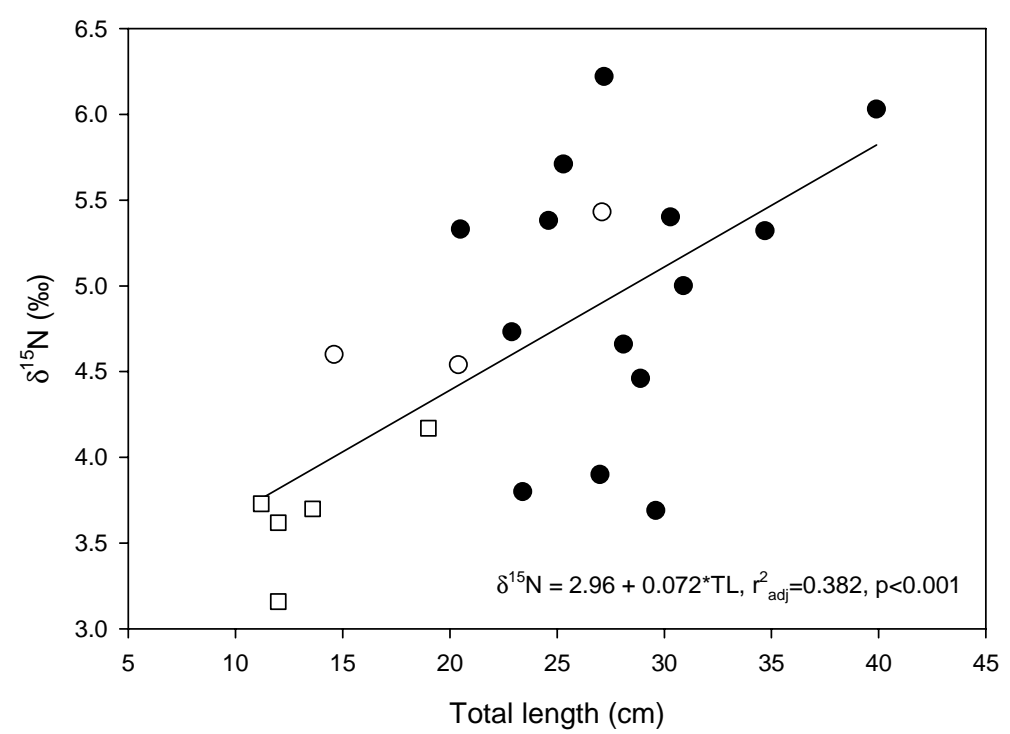

Figure 3. The regression of $\delta^{15} \mathrm{~N}$ vs. total length for Oreochromis niloticus (closed circle), O. leucostictus (open circle) and Sarethorodon galilaeus (open square) grouped together to demonstrate possible size-dependent trends in tilapiine dietary patterns and habitat niches. No significant correlations were found within each tilapiine species. 
$O$. niloticus consumed primarily algae and detritus (Tables 1 and 4), consistent with the low $\delta^{15} \mathrm{~N}$ values of this species. However, the broad range of $\delta^{13} \mathrm{C}(-15.5$ to $-21.9 \%$ ) for O. niloticus (Figure 1$)$, suggests an ability to utilize diverse food items in its native habitat just as it does in habitats where it has been introduced. It is also the largest tilapiine in the Nilotic lacustrine system (Trewavas 1983), which may facilitate a broader diet and provide a competitive advantage over other tilapiines. Coexistence of the four tilapiine species in Lake Albert appears to be due to niche diversification. Furthermore, the opportunistic feeding habits of L. niloticus and O. niloticus, as observed in Lake Albert, may partially account for their success as invasive species in Lakes Victoria and Kyoga.

\section{Estimated dietary consumption and interpretation of results}

Brycinus nurse and Neobola bredoi are known to feed on zooplankton, especially cyclopoid copepods (Green 1971). These species showed elevated $\delta^{15} \mathrm{~N}$ values $(\approx 10.1 \%$; Table 1$)$, higher than many of the piscivorous fish. The diet of $B$. nurse was estimated to contain large fractions of zooplankton (53\%), with a fairly narrow range of allowed values between the 5th and 95th percentiles $(44,60 \%)$. The set of simulated diets for $B$. nurse (Figure 4a) shows two peaks corresponding to zooplankton and anisopterans. This interpretation is supported by the high prevalence of zooplankton in $B$. nurse from the Sudd (Table 4). The common cyclopoid Mesocyclops spp. in Lake Albert is often characterized as a predator of other zooplankton species, and this may explain the higher $\delta^{15} \mathrm{~N}$ values for the bulk zooplankton in this lake. This also supports the interpretation of high $\delta^{15} \mathrm{~N}$ values of $B$. nurse and $N$. bredoi as the result of zooplanktivory, not piscivory. Furthermore, the high $\delta^{15} \mathrm{~N}$ of these zooplanktivorous fish, (comparable to values of piscivorous fishes), indicates that the planktonic food chains are not important to most of the large piscivorous fishes in Albert (with the exception of H. forskahlii). This situation is similar to Lake Victoria, where Rastrineobola argentea, a cyprinid zooplanktivore, also has $\delta^{15} \mathrm{~N}$ signatures comparable to $L$. niloticus and therefore cannot be a 


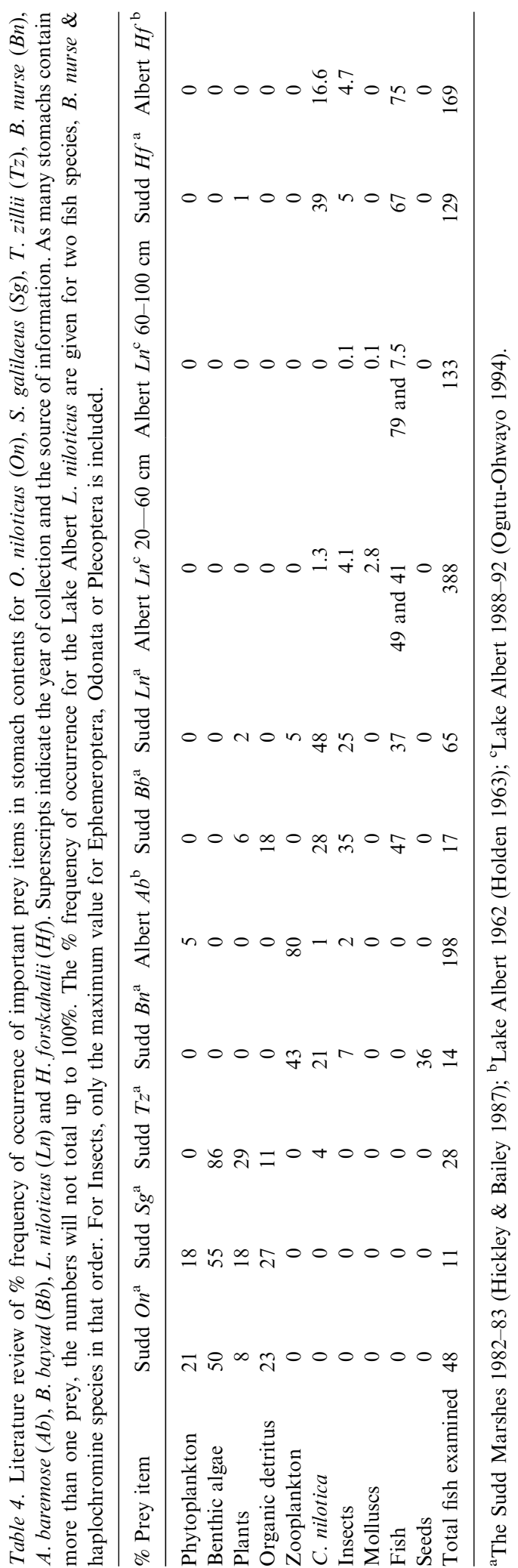

major dietary item for Victoria Nile perch (Campbell et al. 2003a, b).

Alestes baremose was estimated to consume large amounts of C. nilotica (45\%), although the range between the 5th and 95th percentiles was very broad $(4 \%, 85 \%)$ (Table 3 , Figure $4 \mathrm{~b})$. The plot for $A$. baremose showed wide overlaps in possible dietary combinations for each of the four invertebrates. A. baremose in Lake Albert is currently overexploited, with the highest density in the waters of Murchison National Park (near the Victoria Nile) where fishing is restricted (Wandera 2000). A. baremose diets exhibit ontogenetic changes, with significant relationships of $\delta^{15} \mathrm{~N}$ and $\delta^{13} \mathrm{C}$ with total length (Table 2) that suggest a dietary shift from benthic invertebrates to Caridina. In 1928, A. baremose stomachs contained Cladocera, "shells" (unspecified species), insects, macrophytes and haplochromine remains (Worthington 1929). However, in 1962, most A. baremose stomachs contained planktivorous Cladocera (Table 4). During our study, the stomachs of $A$. baremose contained primarily insect nymphs (Table 1). The simulation of $A$. baremose diets (Table 3; Figure 4b), showing greater consumption of benthic invertebrates than zooplankton, agrees with both the Worthington (1929) results and our stomach content observations. Furthermore, large unhelmeted Cladocerans, Daphnia lumholzi, are now more common than smaller helmeted versions (Lehman et al. 1998), indicating that visual zooplanktivory by $A$. baremose currently is not a dominant influence on zooplankton in Lake Albert.

L. niloticus and the catfish Bagrus bayad are piscivorous, but also include invertebrates in their diets (Greenwood 1966). The simulated mean fish consumption for L. niloticus and B. bayad was roughly $50 \%$ (percentile range $18,71 \%$ ), while mean invertebrate intake is estimated to range from 28 to $44 \%$ (percentile range 12, 66\%; Table 3). Frequency plots (Figure 4c-e) reveal high overlap of possible dietary combinations, which suggests that there are multiple dietary sources contributing to the mean isotopic values of those fish species. While to some degree this is an inevitable result of an under constrained parameter search (i.e., Phillips and Greg, 2003), this interpretation is supported by published stomach-contents data (Table 4) that include a 

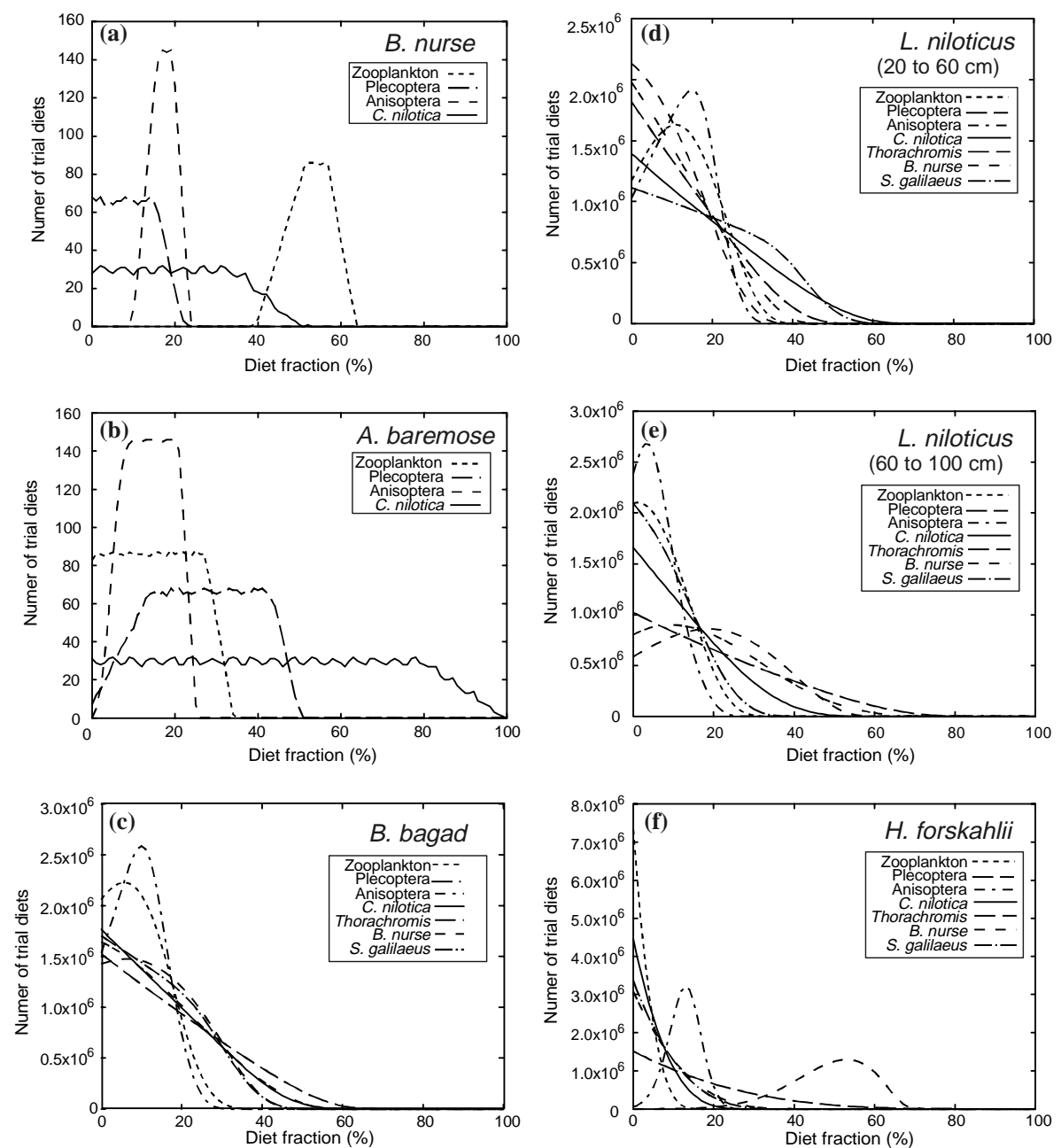

Figure 4. Results from the parameter search for 6 Lake Albert fish species. The graphs show the frequency of a given percentage contribution to the overall diet for each dietary item. B. nurse and H. forskahlii, which are known to have specialized diets, show clearly demarcated peaks for two dietary items that also coincide with literature stomach content data (Table 4). The other fish species, all opportunistic predators, demonstrate multiple overlaps indicating that there are a large number of possible dietary combinations for those species.

broad variety of invertebrates and fish species. In summary, the simulated dietary patterns for these two fish species do not clearly identify dominant dietary components, a finding consistent with generalist feeding patterns recorded from stomach contents (Table 4).

In Lake Albert, only $H$. forskahlii, with its high $\delta^{15} \mathrm{~N}$ values, appeared to consume relatively ${ }^{15} \mathrm{~N}$-enriched B. nurse (Table 3, Figure 1). In the simulated diet, $H$. forskahlii had a narrow range of values (30\% between 5 th and 95 th percentile) and a large dietary contribution from $B$. nurse (Figure 4f). This simulated outcome is supported by published analyses of stomach contents for H. forskahlii collected in 1929 and 1962 from Lake Albert and in the 1980's from the Sudd that revealed high frequencies of fish, mostly $B$. nurse and haplochromines, in their diets (Table 4). In Lake Albert, $H$. forskahlii was and remains the most piscivorous fish species.

Simulating 'probable' diets based on stable isotope values of putative prey and predators 
agreed with published stomach contents data for B. nurse, A. baremose and H. forskahlii. All of these species are known to have relatively specialized diets. For L. niloticus and B. bayad, their more generalist diets were reflected in the wide range of simulated diets found. Frequency plots of successful dietary combinations fitting the isotopic values of target consumers (Figure 4) can be used to assess the importance of particular item to a fish species. Several untested assumptions are implicit in the simulation, including consistent species-specific trophic fractionation, isotopic equilibrium between prey and predator, and no growth-related changes in isotopic signatures. The fact that simulated dietary composition compared favourably with published stomach content data suggests that this independent approach to estimating diet can be used to evaluate food web relationships implied from stable isotopes. Dietary simulations based on static modeling of stable isotope data also can provide insight into which prey are important to the somatic growth of a particular fish (as opposed to items consumed but not contributing to the somatic growth). This is particularly important given that as both laboratory and field assessments of stable isotope ecology in tropical aquatic systems are rare (i.e. Hart et al. 2003).

\section{Acknowledgements}

Richard Ogutu-Ohwayo and Fred Bugenyi, Directors of the Fisheries Resources Research Institute enabled logistical support for expeditions. Rose Muggide, Godfrey Magezi, Vincent Kiggundu, Gertrude Namulemo, the CIDA interns Claire Herbert and Greg Silsbe, the Masindi District Fisheries Officers and the Butiaba fishermen assisted with the sample collection and fish processing. Vincent Nero and William Mark processed the stable isotope samples at the Environmental Isotope Laboratory, University of Waterloo. The computerized parameter searches were run on the SHARCNET computing facilities at McMaster University. Financial support was provided by two International Development Research Council Doctorate Awards, an NSERC PGS-B Scholarship and an Ontario Provincial Graduate Sciences \& Technology Scholarship to
L.M.C., as well as NSERC Discovery Grants to R.E.H. and D.G.D.

\section{References}

Balirwa, J.S. 1992. The evolution of the fishery of Oreochromis niloticus (Pisces: Cichlidae) in Lake Victoria. Hydrobiologia 232: 85-89.

Batjakas, I.E., R.K. Edgar \& L.S. Kaufman. 1997. Comparative feeding efficiency of indigenous and introduced phytoplanktivores from Lake Victoria: Experimental studies on Oreochromis esculentus and Oreochromis niloticus. Hydrobiologia 347: 75-72.

Campbell, L.M., R.E. Hecky, J. Nyaundi, R. Muggide \& D.G. Dixon. 2003a. Distribution and food-web transfer of mercury in Napoleon and Winam Gulfs, Lake Victoria, East Africa. Journal of Great Lakes Research 29 (Supplement 2): 267 282.

Campbell, L.M., R.E. Hecky \& S.B. Wandera. 2003b. Stable isotope analyses of food web structure and fish diet in Napoleon and Winam Gulfs, Lake Victoria, East Africa. Journal of Great Lakes Research 29 (Supplement 2): 243-257.

Davenport, S.R. \& N.J. Bax. 2002. A trophic study of a marine ecosystem off southeastern Australia using stable isotopes of carbon and nitrogen. Can. J. Fisheries Aquat. Sci. 59: 514-530.

Goldschmidt, T., F. Witte \& J. Wanink. 1993. Cascading effects of the introduced Nile perch on the detritivorous/phytoplanktivorous species in the sublittoral areas of Lake Victoria. Conserv. Biol. 7: 686-699.

Green, J. 1971. Associations of Cladocera in the zooplankton of the lake source of the White Nile. J. Zool. London 165: 373414.

Gu, B., C.L. Schelske \& M.V. Hoyer. 1997. Intrapopulation feeding diversity in blue tilapia: evidence from stable-isotope analyses. Ecology 78: 2263-2266.

Hart, R., L.M. Campbell \& R.E. Hecky. 2003. Demographic and stable isotope studies of Lake Victoria Caridina nilotica. Oecologia 136: 270-278.

Harvey, C.J., P.C. Hanson, T.E. Essington, P.B. Brown \& J.F. Kitchell. 2002. Using bioenergetics models to predict stable isotope ratios in fishes. Can. J. Fisheries Aquat. Sci. 59: 115-124.

Hauser, L., G.R. Carvalho, T.J. Pitcher \& R. Ogutu-Ohwayo. 1998. Genetic affinities of an introducted predator: Nile perch in Lake Victoria, East Africa. Mol. Ecol. 7: 849-857.

Hecky, R.E. \& R.H. Hesslein. 1995. Contributions of benthic algae to lake food webs as revealed by stable isotope analyses. N. Am. J. Benthol. Soc. 14: 631-653.

Hickley, P. \& R.G. Bailey. 1987. Food and feeding relationships of fish in the Sudd swamps (River Nile, southern Sudan). J. Fish Biol. 30: 147-159.

Holden, M.J. 1963. Report on the fisheries of Lake Albert. East African Freshwater Fisheries Research Organization, Lowestoft, U.K. 116 pp.

Kabatereine, N.B., E.I. Odongo-Aginya \& T.L. Lakwo. 1996. Schistosoma mansoni along Lake Albert, Kibale District, Western Uganda. East Afr. Med. J. 73: 502-504. 
Kaufman, L. 1992. Catastrophic change in species-rich freshwater ecosystem: The lessons of Lake Victoria. BioScience 42: 846-858.

Keough, J.R., C.A. Hagley, E. Ruzycki \& M. Sierszen. 1998. $\delta^{13} \mathrm{C}$ composition of primary producers and role of detritus in a freshwater coastal ecosystem. Limnol. Oceanogr. 43: 734-740.

Lehman, J.T., A.H. Litt, R. Mugidde \& D.A. Lehman. 1998. Nutrients and plankton biomass in the rift lake sources of the White Nile: Lakes Albert and Edward. pp. 157-172. In: J.T. Lehman (ed.), Environmental Change and Response in East African Lakes, Kluwer Academic Publishers, The Netherlands.

Ogutu-Ohwayo, R. 1994. Adjustments in Fish Stocks and in Life History Characteristics of Nile Perch, Lates niloticus L. in Lakes Victoria, Kyoga and Nabugabo. Ph.D., University of Manitoba, Winnipeg, Manitoba. 213 pp.

Ogutu-Ohwayo, R. \& R.E. Hecky. 1991. Fish introductions in Africa and some of their implications. Can. J. Fisheries Aquat. Sci. 48: 8-12.

Peterson, B.J. \& B. Fry. 1987. Stable isotopes in ecosystem studies. Ann. Rev. Ecol. Syst. 18: 293-320.

Pinnegar, J.K. \& N.V.C. Polunin. 1999. Differential fractionation of $\delta^{13} \mathrm{C}$ and $\delta^{15} \mathrm{~N}$ among fish tissues: implications for the study of trophic interactions. Funct. Ecol. 13: 225231.

Pitcher, T.J. 1995. Species changes and fisheries in African lakes: Outline of the issues. pp. 1-18. In: T.J. Pitcher \& P.J.B. Hart (eds.), The Impact of Species Changes in African Lakes., Chapman \& Hall, London, Great Britain.

Trewavas, E. 1983. Tilapiine Fishes of the Genera Sarotherodon, Oreochromis, and Danakilia. British Museum (Natural History), London UK. 583 pp.

Twongo, T. 1995. Impact of fish species introductions on the tilapias of Lakes Victoria and Kyoga. pp. 45-58. In: T.J. Pitcher \& P.J.B. Hart (eds.), The Impact of Species Changes in African Lakes, Chapman \& Hall, London, Great Britain.

Wandera, S.B. 2000. Report on the current state of the fishery of the Ugandan sector of Lake Albert. pp. 29, Prepared for the FAO subregional representative for Southern and Eastern Africa (SAFD). Fisheries Resources Research Institute., Jinja, Uganda. 29 pp.

Witte, F. \& W.L.T. Densen. 1995. Fish Stocks and Fisheries of Lake Victoria: A Handbook for Field Observations. Samara Publishing Limited, Cardigan, UK. 404 pp.

Worthington, E.B. 1929. A Report on the Fishing Survey of Lakes Albert and Kioga. Conville and Caius College, Cambridge, U.K. 136 pp. 